\title{
POLYPHENOLS AND ANTIOXIDANT ACTIVITY OF CASHEW NUTS FROM CONVENTIONAL AND ORGANIC CULTIVATION IN DIFFERENT STAGES OF PROCESSING
}

\author{
DENISE JOSINO SOARES* \\ JÉSSICA SILVA DO CARMO** \\ JORGIANE DA SILVA SEVERINO LIMA** \\ GERALDO ARRAES MAIA*** \\ PAULO HENRIQUE MACHADO DE SOUSA**** \\ RAIMUNDO WILANE DE FIGUEIREDO*****
}

\begin{abstract}
This research aimed to determine the total extractable polyphenols and the antioxidant activity of cashew nut obtained from conventional and organic cultivation. The study was performed with cashew nuts collected at four stages of processing: after shelling, before peeling, after peeling and during packaging. The antioxidant activity was measured by the methods with the radicals ABTS ${ }^{\circ}$ and $\mathrm{DPPH}^{\cdot}$ and by the $\beta$-carotene/linoleic acid system. The nuts collected in the steps after shelling and before peeling presented higher antioxidant activity than those collected after peeling and during packaging. Little variation occurred in the content of total extractable polyphenols and antioxidant activity by ABTS*+ and DPPH* assays between the two cultivation methods studied.
\end{abstract}

* Doutoranda em Ciência e Tecnologia de Alimentos, Universidade Federal do Ceará (UFC), Fortaleza, CE (e-mail: denisejosino@hotmail.com).

** Graduandas em Engenharia de Alimentos, UFC, Fortaleza, CE (e-mail: jessicacarmo.ufc@gmail.com; eng.jorgynha@hotmail.com).

*** PhD em Ciência dos Alimentos, Professor Emérito, Departamento de Tecnologia de Alimentos, UFC, Fortaleza, CE (e-mail: garraes@pq.cnpq.br).

**** Doutor em Ciência e Tecnologia de Alimentos, Professor, Instituto de Cultura e Arte, UFC, Fortaleza, CE (e-mail: phenriquemachado@gmail.com).

***** Doutor em Ciência dos Alimentos, Professor, Departamento de Tecnologia de Alimentos, UFC, Fortaleza, CE (e-mail: figueira@ufc.br). 


\section{INTRODUCTION}

The cashew tree stands out due to the high nutritional and commercial value of its products (PEREIRA et al., 2005). From the cashew tree the cashew is obtained, which is composed of a cashew nut and a cashew apple.

The cashew apple is a non-climacteric fruit (PAIVA et al., 2003) and has high nutritional value (FAO, 2011) since it is rich in fiber, vitamins, minerals (EMBRAPA and SEBRAE, 2003), sugars and tannins (AZAM-ALI and JUDGE, 2001).

The cashew nut is composed of a shell, skin and kernel. The nut is the main product (LIMA and DUARTE, 2006) and is a source of protein, polyunsaturated fatty acids, carbohydrates, high levels of calcium, iron and phosphorus (PAIVA, GARRUTTI and SILVA NETO, 2000). High levels of flavonoids and other phenolic compounds can be found in the skin which acts synergistically with the vitamins $C$ and $E$ presenting in vitro antioxidant capacity (AMICO et al., 2006) and cardioprotective effect (HEIM, TAGLIAFERRO and BOBILYA, 2002).

The consumption of fruits has been associated with a lower incidence of chronic diseases such as cancer and cardiovascular disease. The protective effect is associated with the high content of bioactive compounds which have important properties, such as antioxidants (HINNEBURG, DORMAN and HILTUNEN, 2006). Due to the presence of bioactive compounds in the composition of nuts, many of them have been identified as being rich in natural antioxidants (WU et al., 2004). However, there are very few works in the literature about the phenolic content and total antioxidant activity of cashew nuts.

The constant quest for healthy food has led to changes in cultivation systems known as the conventional to organic cultivation. The cultivation of vegetables through conventional production allows the use of industrial fertilizers and pesticides. In organic cultivation the use of these substances is not allowed (CHITARRA and CHITARRA, 2005). According to Ormond et al. (2002), the fertilizer of organic cultivation is the organic matter contained in soil.

The processing of cashew nuts includes the following stages: harvesting of cashew, removal of the cashew nut, cleaning, selection, first drying, classification, cooling, shelling, second drying, humidification, third drying, cooling, peeling, packing and storage (PAIVA, SILVA NETO and PESSOA, 2000). During the processing of fruit, losses in some compounds occur, but only few studies about losses in the content of phenolic compounds and antioxidant activity of cashew nuts during processing were found (SAJILATA and SINGHAL, 2006; SOARES et al., 2012).

In order to verify the influence of cultivation method and the processing on the phenolic compounds and antioxidant activity, this research aimed to determine the total extractable polyphenols and the antioxidant activity of the cashew nut from conventional and organic cultivation during various stages of processing.

\section{MATERIAL AND METHODS}

The study was performed with cashew nuts donated by a large company from the Northeast (A. Ferreira Ind. Comércio e Exportação LTDA, AFICEL), located in Mossoró (Rio Grande do Norte, Brazil). The conventional and organic cashew trees studied were cultivated at the same farm (using the same environmental conditions) and belonged to the same specie (Anacardium occidentale) and variety (early dwarf cashew trees).

Cashew nuts from conventional and organic cultivation were collected at four stages of processing: after shelling, before peeling, after peeling and during packaging. These steps were selected in order to check if there were losses in total extractable polyphenols and in antioxidant activity during the processing of these nuts.

Five hundred grams of each cultivation method in each processing step were collected in plastic bags and then crushed using a domestic blend at the time of analysis. 
After preliminary studies, defatted nuts were chosen to perform the determination of total extractable polyphenols and total antioxidant activity, because according to Alasalvar et al. (2006), the extraction of compounds with antioxidant activity is performed more efficiently on defatted samples.

The process to remove the fat consisted of weighing $10 \mathrm{~g}$ of crushed cashew nuts and adding $20 \mathrm{~mL}$ of hexane followed by agitation of the solution for 20 minutes in a magnetic stirrer and subsequent centrifugation at $3000 \mathrm{rpm}$ for 15 minutes. The residue was placed under a hood for complete evaporation of the hexane.

The extract to determine the total extractable polyphenols and the antioxidant activity of nuts was obtained as described by Larrauri, Ruperez and Saura-Calixto (1997) with modifications, as follows: the extract was prepared from the residue obtained through the process to remove the fat. Twenty milliliters of ethanol $50 \%$ was added to the residue, leaving it to extract for 1 hour, and the centrifugation was held at $3000 \mathrm{rpm}$ for 15 minutes. The supernatant was filtered into a $50 \mathrm{~mL}$ volumetric flask. Twenty milliliters of acetone $70 \%$ was added to the residue of this second centrifugation, leaving it to extract for 1 hour and the centrifugation was then repeated. The supernatant was filtered and added to the supernatant obtained at the first extraction, measuring the volume with distilled water.

The total extractable polyphenols was performed according to Larrauri, Ruperez and SauraCalixto (1997) using gallic acid as a standard solution. The reading, at $700 \mathrm{~nm}$, was performed using a spectrophotometer (Shimadzu, UV - 1800 model).

For the determination of the antioxidant activity by ABTS ${ }^{+}$(2,2'-Azino-bis(3ethylbenzothiazoline-6-sulfonic acid) diammonium salt) and DPPH' (2,2-Diphenyl-1-picrylhydrazyl) assays, the extract was used with the following concentrations: 4000, 8000, 12000 and 16000 ppm for nuts collected after shelling and before peeling and 25000, 50000, 100000 and 200000 ppm for cashew nuts collected after peeling and during packaging.

In the $\mathrm{ABTS}^{++}$test, the reading, in a spectrophotometer (Shimadzu, UV - 1800 model), was performed exactly 6 minutes after the mixture of the ABTS ${ }^{++}$radical at $0.700 \pm 0.05$ of absorbance with the phenolic extract of cashew nut, at $734 \mathrm{~nm}$ and using Trolox® (6-hydroxy-2,5,7,8tetramethylchroman-2-carboxylic acid) as a standard antioxidant (RE et al., 1999).

In the DPPH' test, the reading was performed 30 minutes after mixing the cashew nut extract with ethanolic solution of $0.06 \mathrm{mM}$ DPPH'(BRAND-WILLIAMS, CUVELIER and BERSET, 1995). The reading, at $515 \mathrm{~nm}$, was performed using a spectrophotometer (Shimadzu, UV - 1800 model).

The total antioxidant activity was performed by the $\beta$-carotene/linoleic acid system according to Miller (1971). The $\beta$-carotene/linoleic acid system was prepared by adding $80 \mu \mathrm{L}$ of linoleic acid, 28 drops of Tween $40,100 \mu \mathrm{L}$ of $\beta$-carotene solution diluted in chloroform at a concentration of $20 \mathrm{mg} / \mathrm{mL}$ and $2 \mathrm{~mL}$ of chloroform. This solution was placed under a hood for complete evaporation of the chloroform, and then water treated with oxygen was added to obtain the absorbance between 0.600 and 0.700 at a wavelength of $470 \mathrm{~nm}$. Aliquots of $5 \mathrm{~mL}$ of $\beta$-carotene/linoleic acid system were added to a series of tubes containing $0.4 \mathrm{~mL}$ of fruit extract at a concentration of $16000 \mathrm{ppm}$ for cashew nuts collected after shelling and before peeling and 200000 ppm for cashew nuts collected after peeling and during packaging. This difference in concentrations used between the stages of processing was due to the higher or lower levels of antioxidants present in the nut, since it is necessary to perform a greater dilution in nuts with higher antioxidant content. The absorbance of $\beta$-carotene/linoleic acid system was also read and it was used as control water. Trolox® was used as a standard antioxidant. After the addition of the system, the tubes were placed in a water bath at $40^{\circ} \mathrm{C}$. The absorbance of each sample was measured in a spectrophotometer (Shimadzu, UV -1800 model) at $470 \mathrm{~nm}$ at intervals of $15 \mathrm{~min}$, starting immediately after the sample preparation ( $\mathrm{t}=0 \mathrm{~min}$ ) until the end of the experiment $(t=120 \mathrm{~min})$. The antioxidant activity was expressed in two different ways. 
The percentage of antioxidant activity (\%ANT) was calculated as described by Al-Saikhan, Howard and Miller Junior (1995) using the equation 1:

$$
\left.\% A N T=\left(R_{\text {control }}-R_{\text {sample }}\right) /\left(R_{\text {control }}\right)\right) \times 100
$$

$\mathrm{R}_{\text {control }}$ and $\mathrm{R}_{\text {sample }}$ are the average rates of the bleaching system prepared without the addition of antioxidant and of the extract with antioxidant (extract of cashew nuts), respectively.

The $\mathrm{R}_{\text {control }}$ and $\mathrm{R}_{\text {sample }}$ are calculated according to the equation 2:

$$
R=1 / t \times \ln \left(A_{t=0} / A_{t=t}\right)
$$

$R_{\text {control }}$ and $R_{\text {sample }}$ were calculated based on the average rates at three time point. "t" corresponds to the time in minutes $\left(15,30\right.$ or 45 minutes). $A_{t=0}$ is the absorbance of the solution immediately after preparation of the sample (absorbance measured at the time of adding the system solution) and $A_{t=t}$ is the absorbance in the times of 15,30 or 45 min after the addition of the system.

The antioxidant activity (AA) was calculated from the absolute changes in absorbance in the times of 60 and 120 minutes $\left(\mathrm{AA}_{(60 \mathrm{~min})}\right.$ and $\left.\mathrm{AA}_{(120 \mathrm{~min})}\right)$, respectively, according to equation 3 (AMAROWICZ et al., 2004):

$$
A A=\left(1-\left(\left(A_{\text {extract }}\right) /\left(\left(A_{\text {water }}\right)+\left(A_{\text {Trolox }}\right)\right) \times 100\right.\right.
$$

$A_{\text {extract }}=A_{\text {extract }} \mathrm{t}^{\mathrm{a}}-\mathrm{A}_{\text {extract }}^{\mathrm{t}=\mathrm{t}}$

$A_{\text {water }}=A_{\text {water }}{ }^{t}=0-A_{\text {water }} t=t$

$A_{\text {Trolox }}=A_{\text {Trolox }} \mathrm{t}=0-A_{\text {Trolox }} \mathrm{t}=\mathrm{t}$

$t=0$ is the absorbance at the time of 0 minutes and $t=t$ is the absorbance at the times of 60 or 120 minutes.

The experiment was conducted in a Completely Randomized Design, using four treatments (stages of the processing line) and three replications (sampling dates). Analyses were performed in duplicate. The results were statistically evaluated by variance analysis. As evidenced, the significant by the $\mathrm{F}$ test, the treatments were compared by Tukey test at $5 \%$ probability using the statistical program SAS 8.1 (SAS, 2006).

\section{RESULTS AND DISCUSSION}

There was no significant interaction $(p>0.05)$ between the stages of processing and the two forms of cultivation for the total extractable polyphenols and the antioxidant activity by ABTS++ and $\beta$-carotene/linoleic acid system. For these parameters, the results were analyzed comparing the stages of processing and the cultivation form independently (Tables 1 and 2).

There was significant difference $(p<0.05)$ between the processing steps for the total extractable polyphenols, and the higher contents were observed in nuts collected with the skin (after shelling and before peeling) (Table 1).

According to Blomhoffi et al. (2006), most of the phenolic compounds of nuts are found in the skin and less than $10 \%$ are retained when the skin is removed. Kornsteiner, Wagner and Elmadfa (2006) evaluated the content of phenolic compounds in almonds with and without skin and observed that almonds with skin have about $239 \mathrm{mg}$ gallic acid equivalent (GAE)/100 g, and that with the removal of skin this value decreases to $47 \mathrm{mg} \mathrm{GAE} / 100 \mathrm{~g}$. Shahidi, Alasalvar and Pathirana (2007) observed values of total extractable polyphenols of $13.70 \mathrm{mg} \mathrm{GAE} / 100 \mathrm{~g}$ in hazelnuts without skin and $577.70 \mathrm{mg} \mathrm{GAE} / 100 \mathrm{~g}$ in hazelnut skin. 
TABLE 1 - TOTAL EXTRACTABLE POLYPHENOLS (TEP) AND ANTIOXIDANT ACTIVITY BY

ABTS + AND $\beta$-CAROTENE/LINOLEIC ACID SYSTEM OF CASHEW NUTS COLLECTED

AFTER SHELLING, BEFORE PEELING, AFTER PEELING AND DURING PACKAGING, OBTAINED FROM CONVENTIONAL AND ORGANIC CULTIVATION

\begin{tabular}{|c|c|c|c|c|c|}
\hline \multirow{3}{*}{$\begin{array}{l}\text { Collection } \\
\text { stages }\end{array}$} & \multirow{3}{*}{$\begin{array}{c}\text { TEP } \\
(\mathrm{mg} \mathrm{GAE} / 100 \mathrm{~g})\end{array}$} & \multirow{3}{*}{$\begin{array}{c}\text { ABTS }^{\circ+} \\
(\mu \mathrm{M} \text { Trolox/g) }\end{array}$} & \multicolumn{3}{|c|}{$\beta$-carotene/linoleic acid system } \\
\hline & & & ANT (\%) & $\mathrm{AA}_{(60 \mathrm{~min})}(\%)$ & $\mathrm{AA}_{(120 \mathrm{~min})}(\%)$ \\
\hline & & & \multicolumn{3}{|c|}{ Analyzed at 16000 ppm } \\
\hline After shelling & $644.17^{a}$ & $62.74^{a}$ & $78.74^{a}$ & $81.60^{a}$ & $74.43^{a}$ \\
\hline \multirow[t]{2}{*}{ Before peeling } & $504.41^{\mathrm{b}}$ & $32.79^{b}$ & $89.15^{a}$ & $84.39^{a}$ & $75.94^{a}$ \\
\hline & & & \multicolumn{3}{|c|}{ Analyzed at 200000 ppm } \\
\hline After peeling & $133.66^{c}$ & $8.40^{c}$ & $87.35^{\mathrm{a}}$ & $92.30^{\mathrm{a}}$ & $91.61^{a}$ \\
\hline During packaging & $61.62^{\mathrm{d}}$ & $6.38^{d}$ & $78.15^{b}$ & $84.49^{b}$ & $84.31^{a}$ \\
\hline
\end{tabular}

* Same letters within the same column are not statistically different by Tukey test ( $p \leq 0.05)$.

** The results from the $\beta$-carotene/linoleic acid system were compared between nuts analyzed at the same concentration

${ }^{* * *}$ ANT = percentage of antioxidant activity; $A A=$ antioxidant activity.

There was significant difference $(p<0.05)$ between the two cultivations forms for the total extractable polyphenols. The highest level was observed in nuts from organic cultivation (346.34 mg $\mathrm{GAE} / 100 \mathrm{~g}$ ), while nuts from conventional cultivation presented $325.59 \mathrm{mg} \mathrm{GAE} / 100 \mathrm{~g}$.

The same behavior found for the total extractable polyphenols is expected in the result of antioxidant activity, because the highest levels of this bioactive compound in cashew nuts are found in the skin. The results of the antioxidant activity by the $\mathrm{ABTS}^{++}$radical were higher in the early stages of the process (nuts collected with skin), being 62.74 and $32.79 \mu \mathrm{M}$ Trolox/g in nuts collected after shelling and before peeling, respectively (Table 1).

The highest values of antioxidant activity by $\mathrm{ABTS}^{++}$were observed in the nuts from organic cultivation $(28.08 \mu \mathrm{M}$ Trolox $/ g)$, significantly differing $(p<0.05)$ of nuts from conventional cultivation (27.07 $\mu \mathrm{M}$ Trolox/g) (Table 2). This variation in antioxidant activity can be attributed to differences that may have occurred during the processing of nuts and the differences between the content of total extractable polyphenols observed in both forms of cultivation studied.

\section{TABLE 2 - TOTAL EXTRACTABLE POLYPHENOLS (TEP) AND ANTIOXIDANT ACTIVITY BY ABTS॰+, DPPH'AND $\beta$-CAROTENE/LINOLEIC ACID SYSTEM OF CASHEW NUTS COLLECTED IN DIFFERENT STAGES OF PROCESSING OBTAINED FROM CONVENTIONAL AND ORGANIC CULTIVATION}

\begin{tabular}{|c|c|c|c|c|c|c|}
\hline \multirow{2}{*}{$\begin{array}{l}\text { Cultivation } \\
\text { forms }\end{array}$} & \multirow{2}{*}{$\begin{array}{c}\text { TEP (mg } \\
\text { GAE/100 } \\
\text { g) }\end{array}$} & \multirow{2}{*}{$\begin{array}{c}\text { ABTS } \\
(\mu \mathrm{M} \\
\text { Trolox/g) }\end{array}$} & \multirow{2}{*}{$\begin{array}{c}\mathrm{DPPH}^{\cdot} \\
\text { (g nut/g } \\
\left.\mathrm{DPPH}^{+}\right)\end{array}$} & \multicolumn{3}{|c|}{$\beta$-carotene/linoleic acid system } \\
\hline & & & & ANT $(\%)$ & $\mathrm{AA}_{(60 \mathrm{~min})}(\%)$ & $\mathrm{AA}_{(120 \mathrm{~min})}(\%)$ \\
\hline Conventional & $325.59^{b}$ & $27.07^{\mathrm{b}}$ & $12108.70^{b}$ & $86.99^{a}$ & $87.38^{a}$ & $83.30^{\mathrm{a}}$ \\
\hline Organic & $346.34^{a}$ & $28.08^{a}$ & $13050.30^{a}$ & $79.70^{\mathrm{a}}$ & $84.01^{a}$ & $79.84^{a}$ \\
\hline
\end{tabular}

* Same letters within the same column are not statistically different by Tukey test ( $p \leq 0.05)$

${ }^{* *}$ ANT = percentage of antioxidant activity; AA = antioxidant activity. 
There was significant interaction $(p<0.05)$ between the stages of processing and the two forms of cultivation for the antioxidant activity by DPPH method, which indicates that there were significant differences $(p<0.05)$ among the stages of processing, either between two forms of cultivation, or between both stages of processing and methods of cultivation together. In order to know where this difference occurred, the individual results were studied (Table 3).

TABLE 3 - ANTIOXIDANT ACTIVITY BY DPPH* (g NUT/g of DPPH') OF CASHEW NUTS COLLECTED AFTER SHELLING, BEFORE PEELING, AFTER PEELING AND DURING PACKAGING OBTAINED FROM CONVENTIONAL AND ORGANIC CULTIVATION

\begin{tabular}{ccc}
\hline \multirow{2}{*}{ Collection stages } & \multicolumn{2}{c}{ Cultivation forms $^{*}$} \\
\cline { 2 - 3 } & Conventional & Organic \\
\hline After shelling & $2398.77^{\mathrm{c}}$ & $2493.53^{\mathrm{c}}$ \\
Before peeling & $2521.59^{\mathrm{c}}$ & $2281.99^{\mathrm{c}}$ \\
After peeling & $10543.57^{\mathrm{b}}$ & $10300.77^{\mathrm{b}}$ \\
During packaging & $32970.77^{\mathrm{a}}$ & $37124.87^{\mathrm{a}}$ \\
\hline
\end{tabular}

* Same letters within the same column are not statistically different by Tukey test $(p \leq 0.05)$.

The values of antioxidant activity by DPPH' were higher in nuts collected at during packaging

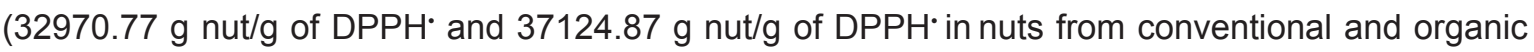
cultivation, respectively) (Table 3 ). These values are very high, indicating a low antioxidant capacity in nuts without skin. These results are consistent since in the DPPH ${ }^{\cdot}$ assay the results are expressed according to the quantity of nut required to reduce $50 \%$ of the initial concentration of $\mathrm{DPPH}$ radical. Thus, a high DPPH' result means that the sample has a low antioxidant activity.

There was significant difference $(p<0.05)$ between the results of antioxidant activity by the $\mathrm{DPPH}^{\cdot}$ assay in both forms of cultivation studied (Table 2 ) and the highest results were found in organic nuts.

The percentage level of antioxidant activity was higher than $74 \%$ in nuts collected after shelling and before peeling, showing that even in the low concentration studied the cashew nuts have high antioxidant activity (Table 1).

There was no significant difference $(p>0.05)$ between nuts collected after shelling and before peeling (analyzed at concentration of $16000 \mathrm{ppm}$ ) for the antioxidant activity in the times of 60 and 120 minutes, the same was observed for antioxidant activity in the time of 120 minutes in cashew nuts collect after peeling and during packaging (analyzed at concentration of $200000 \mathrm{ppm}$ ) (Table 1).

Comparing the antioxidant activity of nuts analyzed at a concentration of $200000 \mathrm{ppm}$ (after peeling and during packaging) with those analyzed at a concentration of $16000 \mathrm{ppm}$ (after shelling and before peeling), it is possible to say that nuts collected in steps after shelling and before peeling have higher antioxidant activity than those collected after peeling and during packaging, as high levels of antioxidants in nuts analyzed in the concentration of $16000 \mathrm{ppm}$ were observed, and a higher concentration (200000 ppm) had to be used to obtain antioxidant activity similar to that observed in the first.

The antioxidant activity decreased during the analysis, which can be observed when analyzing the antioxidant activity at 60 minutes and 120 minutes of analysis, where, in the four stages of collection and the two forms of cultivation studied, the antioxidant activity in the time of 60 minutes was higher than that observed with 120 minutes of analysis (Table 1). 
The difference in the percentage of antioxidant activity and antioxidant activity in the times of 60 and 120 minutes can be explained by longer exposure of the system at the temperature of $40^{\circ} \mathrm{C}$ which favors the auto-oxidation of linoleic acid in the system solution. According to Jayaprakash et al. (2007), the auto-oxidation of linoleic acid generates free radicals, which interact with the $\beta$-carotene resulting in a decrease in the absorbance of the solution.

Comparing nuts collected after peeling and during packaging it is possible to observe that the highest values of \%ANT e $\mathrm{AA}_{(60 \mathrm{~min})}$ were in cashew nuts collected after peeling, differing significantly $(p \leq 0.05)$ from those collected the during packaging of the conventional cultivation (Table 1).

The reduction of the antioxidant during processing was apparent in the three methods used to quantify the antioxidant activity studied. This can be explained by the antioxidant decomposition when exposed to high temperatures during processing (HINNEBURG, DORMAN and HILTUNEN, 2006), by the exposure to the oxygen during the cooling step which is performed under ambient conditions and by removal of the film which is rich in phenolic compounds.

According to Trox et al. (2010), cashew nut has appreciable levels of carotenoids and tocopherols. Studies show that carotenoids are easily degraded during processing and this degradation increases according to the time and the temperature of processing (ALVES et al., 2008) and tocopherols are sensitive to light and oxygen (TROX et al., 2010). The decomposition of these two bioactive compounds may reduce the antioxidant activity of the fruit.

Antioxidant activity decrease during food processing is to be expected and has been studied by other authors in different fruit products. Mezadri et al. (2008) studied the antioxidant activity of acerola (Amazon cherry) products and concluded that higher levels of processing lower their antioxidant capacity.

There was significant difference $(p<0.05)$ between the two forms of cultivation studied for the total extractable polyphenols and the antioxidant activity by ABTS ${ }^{+}$and DPPH assays (Table 2). The observed difference may be due to greater sensibility of these methods, since the antioxidant activity by $\beta$-carotene/linoleic acid system did not show significant difference $(p>0.05)$ between the two cultivation forms.

\section{CONCLUSION}

The nuts collected at the steps after shelling and before peeling had a higher content of total extractable polyphenols and antioxidant activity than the nuts collected after peeling and during packaging.

There was a reduction in the antioxidant activity during the processing. This was mainly due to the removal of the skin, but may also have occurred due to the high temperature of processing.

Further studies should be performed in order to obtain better time-temperature of drying and prevent the loss of antioxidant compounds in cashew nut and to know the composition of the skin if it does not have harmful compounds, their use in human food can be given as being a good source of antioxidant compounds.

Little variation occurred in the content of total extractable polyphenols and antioxidant activity by $\mathrm{ABTS}^{++}$and $\mathrm{DPPH} \cdot$ assays between the two methods of cultivation, confirming that the cultivation form can cause variation of these parameters in cashew nut.

\section{RESUMO}

\section{POLIFENOIS EXTRAÍVEIS TOTAIS E ATIVIDADE ANTIOXIDANTE DA AMÊNDOA DE CASTANHA DE CAJU PROVENIENTE DE CULTIVOS CONVENCIONAL E ORGÂNICO EM DIFERENTES ETAPAS DO PROCESSAMENTO}

Esta pesquisa teve como objetivo determinar os polifenois extraíveis totais e a atividade antioxidante da amêndoa de castanha de caju, obtida de cultivos convencional e orgânico. O estudo foi realizado com 
amêndoas de castanha de caju coletadas em quatro etapas do processamento: após a decorticação, antes da despeliculagem, após a despeliculagem e na embalagem. A atividade antioxidante foi determinada pelos métodos com os radicais $\mathrm{ABTS}^{*+}$ e DPPH' e pelo sistema $\beta$-caroteno/ácido linoleico. As amêndoas coletadas nas etapas após a decorticação e antes da despeliculagem apresentaram maior atividade antioxidante do que as amêndoas coletadas após a despeliculagem e na embalagem. Ocorreu pequena variação no conteúdo de polifenois extraíveis totais e na atividade antioxidante determinada pelos métodos $\mathrm{ABTS}^{{ }^{+}}$e $\mathrm{DPPH}^{*}$ entre as duas formas de cultivo estudadas.

\section{PALAVRAS-CHAVE: ATIVIDADE ANTIOXIDANTE; CASTANHA DE CAJU; AGRICULTURA ORGÂNICA.}

\section{REFERENCES}

1 ALASALVAR, C.; KARAMACÄ, M.; AMAROWICZ, R.; SHAHIDI, F. Antioxidant and antiradical activities in extracts of hazelnut. Journal of Agricultural and Food Chemistry, v. 54, n. 13, p. 4826-4832, 2006.

2 AL-SAIKHAN, M. S.; HOWARD, L. R.; MILLER JUNIOR, J. C. Antioxidant activity and total phenolics in different genotypes of potato (Solanum tuberosum L.). Journal of Food Science, v. 60, n. 2, p. 341-347, 1995.

3 ALVES, C. C. O.; RESENDE, J. V.; CRUVINEL, R. S. R.; PRADO, M. E. T. Estabilidade da microestrutura e do teor de carotenóides de pós obtidos da polpa de pequi (Caryocar brasiliense Camb.) liofilizada. Ciência e Tecnologia de Alimentos, v. 28, n. 4, p. 830-839, 2008.

4 AMAROWICZ, R.; PEGG, R. B.; RAHIMI-MOGHADDAM, P.; BARL, B.; WEIL, J. A. Free-radical scavenging capacity and antioxidant activity of selected plant species from the Canadian prairies. Food Chemistry, v. 84, n. 4, p. 551-562, 2004.

5 AMICO, V.; BARRESI, V.; CONDORELLI, D.; SPATAFORA, C.; TRINGALI, C. Antiproliferative terpenoids from almond hulls (Prunus dulcis): identification and structure-activity relationships. Journal of Agricultural and Food Chemistry, v. 54 , n. 3, p. 810-814, 2006.

6 AZAM-ALI, S. H.; JUDGE, E. C. Small-scale cashew nut processing. Warwickshire, UK: Rugby, 2001. 70 p.

7 BLOMHOFFI, R.; CARLSEN, M. H.; ANDERSEN, L. F.; JACOBS JR, D. R. Health benefits of nuts: potential role of antioxidants. British Journal of Nutrition, v. 96, n. 2, p. 52-60, 2006.

8 BRAND-WILLIAMS, W.; CUVELIER, M. E.; BERSET, C. Use of free radical method evaluate antioxidant activity. Food Science and Technology, v. 28, n. 1, p. 25-30, 1995.

9 CHITARRA, M. I. F; CHITARRA, A. B. Pós-Colheita de frutas e hortaliças: fisiologia e manuseio. 2. ed. Lavras: Universidade Federal de Lavras, 2005. 783 p.

10 EMBRAPA/SEBRAE. Embrapa Agroindústria Tropical/Serviço Brasileiro de Apoio às Micro e Pequenas Empresas. Iniciando um pequeno grande negócio agroindustrial: castanha de caju. Brasília: Embrapa Informação Tecnológica, 2003. 9 p. (Série Agronegócios).

11 FAO. Food and Agriculture Organization of the United Nations. Integrated production practices of cashew in Asia. 2010. Available at: http://www.fao.org/docrep/005/ac451e/ac451e0b.htm. Accessed on: 10 Apr. 2011.

12 HEIM, K. E.; TAGLIAFERRO, A. R.; BOBILYA, D. J. Flavonoid antioxidants: chemistry, metabolism and structure-activity relationships. The Journal of Nutritional Biochemistry, v. 13, n. 10, p. 572-584, 2002.

13 HINNEBURG, I.; DORMAN, H. J.; HILTUNEN, R. Antioxidant activities of extracts from selected culinary herbs and spices. Food Chemistry, v. 97, n. 1, p. 122-129, 2006.

14 JAYAPRAKASHA, G. K.; NEGI, P. S.; JENA, B. S.; RAO, J. M. Antioxidant and antimutagenic activities of Cinnamomum zeylanicum fruit extracts. Journal of Food Composition and Analysis, v. 20, n. 3-4, p. 330-336, 2007.

15 KORNSTEINER, M.; WAGNER, K. H.; ELMADFA, I. Tocopherols and total phenolics in 10 different nut types. Food Chemistry, v. 98, n. 2, p. 381-387, 2006.

16 LARRAURI, J. A.; RUPEREZ, P.; SAURA-CALIXTO, F. Effect of drying temperature on the stability of polyphenols and antioxidant activity of red grape pomace peels. Journal of Agricultural and Food Chemistry, v. 45, n. 4, p. 1390-1393, 1997.

17 LIMA, J. R.; DUARTE, E. A. Pastas de castanha-de-caju com incorporação de sabores. Pesquisa Agropecuária Brasileira, v. 41, n. 8, p. 1333-1335, 2006.

18 MEZADRI, T.; VILLAÑO, D.; FERNÁNDEZ-PACHÓN, M. S.; GARCÍA-PARRILLA, M. C.; TRONCOSO, A. M. Antioxidant compounds and antioxidant activity in acerola (Malpighia emarginata DC.) fruits and derivates. Food Chemistry, v. 21, n. 4, p. 282-290, 2008. 
19 MILLER, H. E. A simplified method for the evaluation of antioxidant. Journal of the American Oil Chemists' Society, v. 48, n. 2, p. 91,1971

20 ORMOND, J. G. P.; PAULA, S. R. L.; FAVERET FILHO, P.; ROCHA, L. T. M. Agricultura orgânica: quando o passado é futuro. Rio de Janeiro: BNDES Setorial, 2002. 34 p.

21 PAIVA, F. F. A.; GARRUTTI, D. S.; SILVA NETO, R. M. Aproveitamento industrial do caju. Fortaleza: Embrapa CNPAT/SEBRAE/CE, 2000. 9 p.

22 PAIVA, F. F. A.; LEITE, L. A. S.; PESSOA, P. F. A. P.; SOUZA NETO, J.; SÁ, F. T.; SILVA NETO, R. M. S.; FERNANDES A. R. Projetos de empreendimentos agroindustriais: produtos de origem vegetal. Viçosa: Universidade Federal de Viçosa, 2003. v. 2.

23 PAIVA, F. F. A.; SILVA NETO, R. M.; PESSOA, P. F. A. P. Minifábrica de processamento de castanha de caju. Fortaleza: Embrapa Agroindústria Tropical, 2000. 22 p.

24 PEREIRA, M. C. T.; CORREA, H. C. T.; NIETSCHE, S.; MOTA, W. F.; MARQUES, S. V. Caracterização físico-química de pedúnculos e castanhas de clones de cajueiro-anão precoce nas condições do norte de Minas Gerais. Bragantia, v. 64, n. 2, p. 169-175, 2005

25 RE, R.; PELLEGRINI, N.; PROTEGGENTE, A.; PANNALA, A.; YANG, M.; RICE-EVANS, C. Antioxidant activity applying an improved ABTS radical cation decolorization assay. Free Radical Biology \& Medicine, v. 26, n. 9-10, p. 1231-1237, 1999.

26 SAJILATA, M. G.; SINGHAL, R. S. Effect of irradiation and storage on the antioxidative activity of cashew nuts. Radiation Physics and Chemistry, v. 75, n. 2, p. 297-300, 2006.

27 SAS INSTITUTE INC. Statistical software. Version 8.1. Cary, NC, 2006.

28 SHAHIDI, F.; ALASALVAR, C.; PATHIRANA, C. M. L. Antioxidant phytochemicals in hazelnut kernel (Corylus avellana L.) and hazelnut byproducts. Journal of Agricultural and Food Chemistry, v. 55, n. 4, p. 1212-1220, 2007.

29 SOARES, D. J.; CÂMARA, C. R. S.; FIGUEIREDO, E. A. T. de; MAIA, G. A.; SOUSA, P. H. M. de; FIGUEIREDO, R. W. Characterization and antioxidant activity of cashew nut bran in different stages of processing. Boletim do CEPPA, v. 30, n. 1, p. 147-153, 2012

30 TROX, J.; VADIVEL, V.; VETTER, W.; STUETZ, W.; SCHERBAUM, V.; GOLA, U.; NOHR, D.; BIESALSKI, H. K. Bioactive compounds in cashew nut (Anacardium occidentale L.) kernels: effect of different shelling methods. Journal of Agricultural and Food Chemistry, v. 58, n. 9, p. 5341-5346, 2010.

31 WU, X.; BEECHER, G. R.; HOLDEN, J. M.; HAYTOWITZ, D. B.; GEBHARDT, S. E.; PRIOR, R. L. Lipophilic and hydrophilic antioxidant capacities of common foods in the United States. Journal of Agricultural and Food Chemistry, v. 52, n. 12, p. 4026-4037, 2004. 